제주산 펄닭새우, Linuparus trigonus(Von Siebold)의 성숙과 산란

\author{
이한나 · 최정화*1 - 임양재 ${ }^{2} \cdot$ 유준택' - 오택 윤' - 김정 년' \\ 국립수산과학원 수산동물방역센터, ${ }^{1}$ 국립수산과학원 자원연구과, \\ ${ }^{2}$ 국립수산과학원 서해수산연구소 자원환경과
}

\title{
Maturation and spawning of Japanese spear lobster, Linuparus trigonus(Von Siebold) in Jeju Island
}

\author{
Han Na Lee, Jung Hwa CHOI*1, Yang Jae IM², Joon Taek Yoo ${ }^{1}$ Taeg Yun $\mathrm{OH}^{1}$ and Jung Nyun KIM ${ }^{1}$ \\ Food Safety Research Division, National Fisheries Research and Development Institute, \\ Busan 619-902, Korea \\ ${ }^{1}$ Fisheries Resources Research and Management Division, NFRDI, Busan 619-902, Korea \\ ${ }^{2}$ Fisheries Resources and Environment Division, West Sea Fisheries Research Institute, \\ NFRDI, Inchon 400-420, Korea
}

This study examined the maturation and main spawning season of Japanese spear lobsters, Linuparus tirgonus(Von Siebold) captured around Jeju island from January to September, 2008. Carapace length(CL), body weight(BW) and gonad weight(GW) were measured. Gonadosomatic index(GSI) and sex ratio were calculated. In female group, CL showed the highest value in June and decreased after August. GW showed a peak in July and decreased rapidly after August. The mean gonadosomatic Index(GSI) reached a maximum value between June and August. Number of egg ranged from 143,360 to 189,504.

Key words : Linuparus trigonus, Maturation, Spawning, Jeju Island

\section{서 론}

펄 닭새 우, Linuparus trigonus(Von Siebold) 는 십각목(Decapoda) 닭새우과(Palinurudae)에 속하 며, 일본, 호주, 필리핀을 포함한 인도-태평양
연안의 수심 $30-318 \mathrm{~m}$ 의 사니질에 주로 서식하 고, 전 세 계적으로 149 종이 보고되어 있다 (Holthuis, 1991). 우리나라에서는 제 주도 연 안에 서식하는 것으로 알려져 있다(Kim, 1977).

*Corresponding author: choijh@nfrdi.go.kr, Tel: 82-51-720-2291, Fax: 82-51-720-2277 
펄 닭재우는 해저바닥의 계곡과 같은 은신처 에 주로서식하며(Bishop and Williams, 1986), 이 매패류, 복족류, 갑각류와 다모류 등 소형의 저 속유영 저서생물을 주로 섭이한다(Wassenberg and Hill, 1989). Kim(1977) 은 제 주연 안에 서식하 는 펄 닭새우의 생식소 발달에 따른 생식세 포형 성 과정 및 유 생단계의 형태적 특징을 밝혔다. 또 한, 생식소의 조직학적 분석을 통한 발달단계별 특징(Haddy et al., 2003) 및 종묘생산을 위한 실 험 실 내 유생단계별의 형태적 특징에 관한 연구 (Lipcius and Cobb, 1994) 가 우리나라와 뉴질랜드 에서 보고되었으며, 최근, Haddy et al.(2007)에 의해 펼닭새우 초기 발생단계의 분포특성에 관 해 밝혀졌다. 하지만, 펄 닭새 우의 생식소의 발달 단계별 특성을 통한 성숙과 산란기의 추정은 아 직 보고되어있지 않다.

따라서 본 연 구에서는, 제주산 펄 닭새 우의 성 숙 및 산란 특성을 파악하고 주산란기 추정 및 부착된 난의 형태적 특징을 파악하였다.

\section{재료 및 방법}

본 연 구에 사용된 펄 닭새 우는 제 주도 한림, 서 귀포, 위미 둥 연근해 수심 70-80m 지점에서 2008년 1 월 부터 2008 년 9 월 사이에 매월 저인망 과 자망어획으로 채집되었다. 교접기 와 교미기 의 유무로 성을 구별하였으며, 성비는 수컷에 대 한 암컷 비로써 나타내 었다. 체 장조성과 성장 및 상대포란수를 퐈악하기 위해 갑각장(Carapace length: CL)을 안병의 기저에서 두흥갑의 등면 뒤쪽의 오목한 부분까지 $0.1 \mathrm{~mm}$ 수준으로 버니 어캘리퍼스로 측정하였고, 체 중(Body weight: $\mathrm{BW}$ )과 암컷의 생식소 중랑을 $0.1 \mathrm{~g}$ 까지 전자저 울을 이용하여 측정하였다. 생식소 숙도지수 (Gonadosomatic Index: GSI) 는 생식소 중랭 체 중 $\times 100$ 으로 구하였다.

생식소 발달의 조직학적 분석을 위하여, 암 수의 생식소를 Davidson's 고정액에 고정하였 다. 고정된 생식소는 24 시간 후 수세하고, $70 \%$
에서 $100 \%$ 순차농도 알코올에 탈수하였다. 틸 수된 생식소는Xylene 투명화 및 퐈라핀 친화를 거쳐 파라푄포매 후, microtome을 사용하여 약 $4 \mu \mathrm{m}$ 두께로 박절하였다. 절편은 $\mathrm{H} \& \mathrm{E}$ 염색표본 으로 제 작한 후 광학현미경으로 관찰하였다. 생 식소의 발달단계 특성을 관찰할 수 있는 부분은 디지털 사진촬영 장치를 이용하여 촬영하였다. 생식소의 발달단계는 $\operatorname{Kim}(1977)$ 에서 제시한 생 식소의 조직 발달단계를 참고하여 1 단계부터 5 단계(1 단계: 미성숙, 2 단계: 중숙, 3 단계: 성숙, 4 단계: 방란 중, 5 단계: 방란 후)까지 분리하여 검경하였다.

포란수는 외포란 개체의 외포란을 적 출하여 균등분힐 $(1 / \mathrm{n})$ 한 뒤, 분할 부의 외포란 수를 계수 하고 계수결과와 분할횟수를 곱하여 구하였다.

\section{결과 및 고찰}

연 구기간 동안 어 획된 펄 닭새 우는 갑각장 Fig. 1 과 같이 $99.6-155.7 \mathrm{~mm}$ 으로 $120.0-135.0 \mathrm{~mm}$ 개체가 전체의 $71.6 \%$ 를 차지하였고, 6 월 에 채집 된 개체의 평균갑각장이 $133.0 \mathrm{~mm}$ 로 가장 컸으 며 9월에 채집된 개체의 평균 갑각장이 117.0 $\mathrm{mm}$ 로 가장작았다. 펄 닭새 우 성 비는 Fig. 2 와 같 이 $0.95: 1$ 로 수컷이 암컷에 비해 높은 출현율을 나타내었고, 암컷의 출현비 율이 2 월에 최 고치를

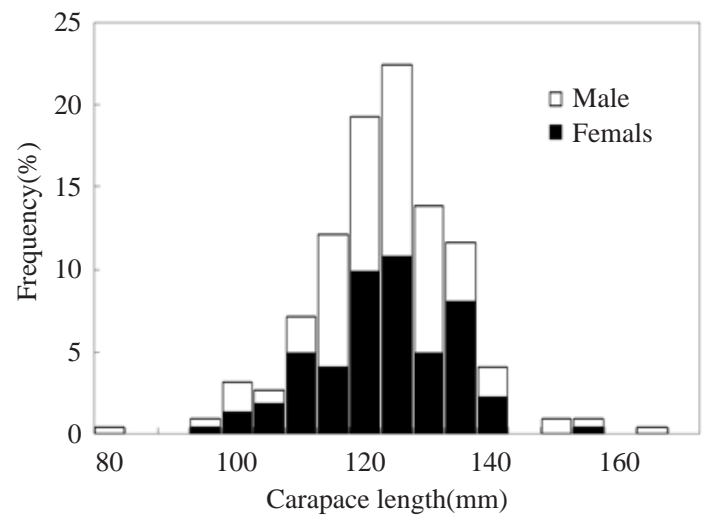

Fig. 1. Size-frequency histograms for Linuparus trigonus sampled between February and September 2008 . Lobsters grouped into $5 \mathrm{~mm}$ CL size classes. 


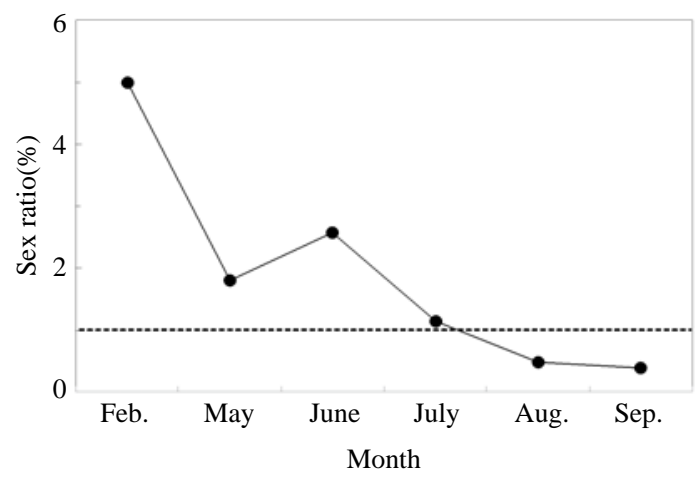

Fig. 2. Monthly variation in sex ratio of Linuparus trigonus. The dotted line indicates a ratio of 1:1(female : male).

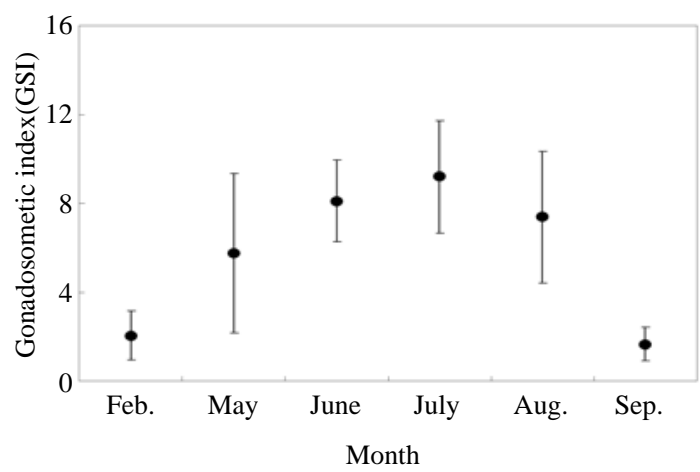

Fig. 3. Changes in the gonadosomatic index(GSI) in monthly samples of female Linuparus trigonus from February to September 2008.

보인 이후 지속적으로 감소하여 7 월 이후 수컷 이 암컷비율보다 높았다. 암컷의 생식소평균 숙 도지수는 Fig. 3 에서와 같이 1.6 이 었으며, 7 월 에 9.2 로 최고였으며, 9 월에 1.7 로 최저였다. 암컷 개체의 크기에 따른 생식소의 발달단계의 결과 는 Fig. 4 와 Fig. 5 와 같이 나타났는데, 갑각장 $105.0 \mathrm{~mm}$ 이 상의 개체부터 성숙단계인 Stage 3 의 비율이 $50 \%$ 이 상으로 나타났으며, 외 포란 암 컷 은 8 월 과 9 월 각각 1 개체씩 출현하였다. 본 연 구에서 나타난 월 별 펄 닭새 우 암컷의 출현비율 과 생식소 숙도지수 변화양상 결 과, 6 월 이후 성 숙한 암컷은 생식소가 발달하기 시 작하여 8월 과 9 월에 외포란하게 되는 것으로 추측되어지나, 포란한 암컷의 출현개체의 비율이 매우 낮있다.

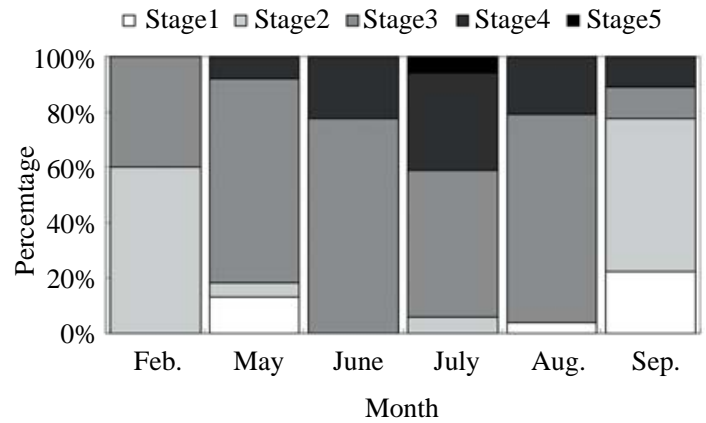

Fig. 4. Percentage of female Linuparus trigonus with ovary mature stage in monthly samples from February to September 2008.

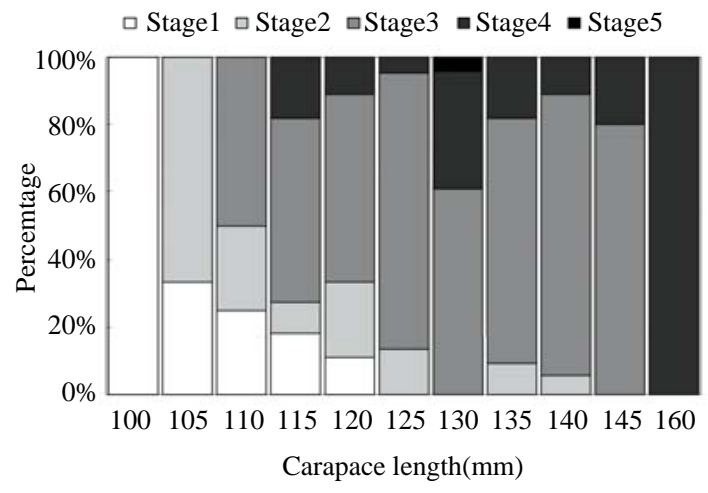

Fig. 5. Percentage of female Linuparus trigonus with ovary mature stage in each size class.

Haddy et al.(2007)은 퀸스랜드에 서식하는 펄 닭 새우 암컷 생식소를해부학적으로 검경하여 난 소의 색, 크기, 난모세 포 육안확인 유무 등을 통 해 미성숙, 성숙중, 성숙, 방란 및 퇴화의 5 가지 단계로 구분하였는데 $65.0 \mathrm{~mm}$ 에서 성숙한 개체 가 출현하기 시작하여 $80.0 \mathrm{~mm}$ 에서 $50 \%$ 이상 의 성숙개체 출현비율을 보인 것으로 보고하였 다. 이러한 성숙개체 크기 차이는 서식수온에 따 른 성장과 성숙의 차이에 의해 기인한 것으로 여 겨진다(Choi et al., 2005).

본 연구의 펄닭새우 암컷 생식소의 조직학적 검경 결 과, 2 월 부터 6월 까지는 성숙된 상태였는 데 6 월부터 갈수록 난경이 증가하고 난모세 포 내 유구의 양적변 동이 있었으며, 7 월 과 8 월 에는 여포층이 두꺼워지고, 핵이 보이지 않거나 가장 
자리로 밀려나 있는 완전성숙 단계의 생식소를 가진 개체가 출현하기 시작하였다. 9월에 채집 한 개체에서는 생식소가 완전성숙한 개체와 미 성숙 난모세포로 구성된 생식소를 가진 개체가
모두 출현하여, 외포란으로 방란이 이루어진 것 으로 나타났다(Fig. 6). 이는 제주 한림에서 채집 한 펄 닭새우의 생 식주기가 9 월 부터 12 월 까지 의 분열증식 기, 1 월 부터 3 월 까지 의 성 장기, 4 월 부
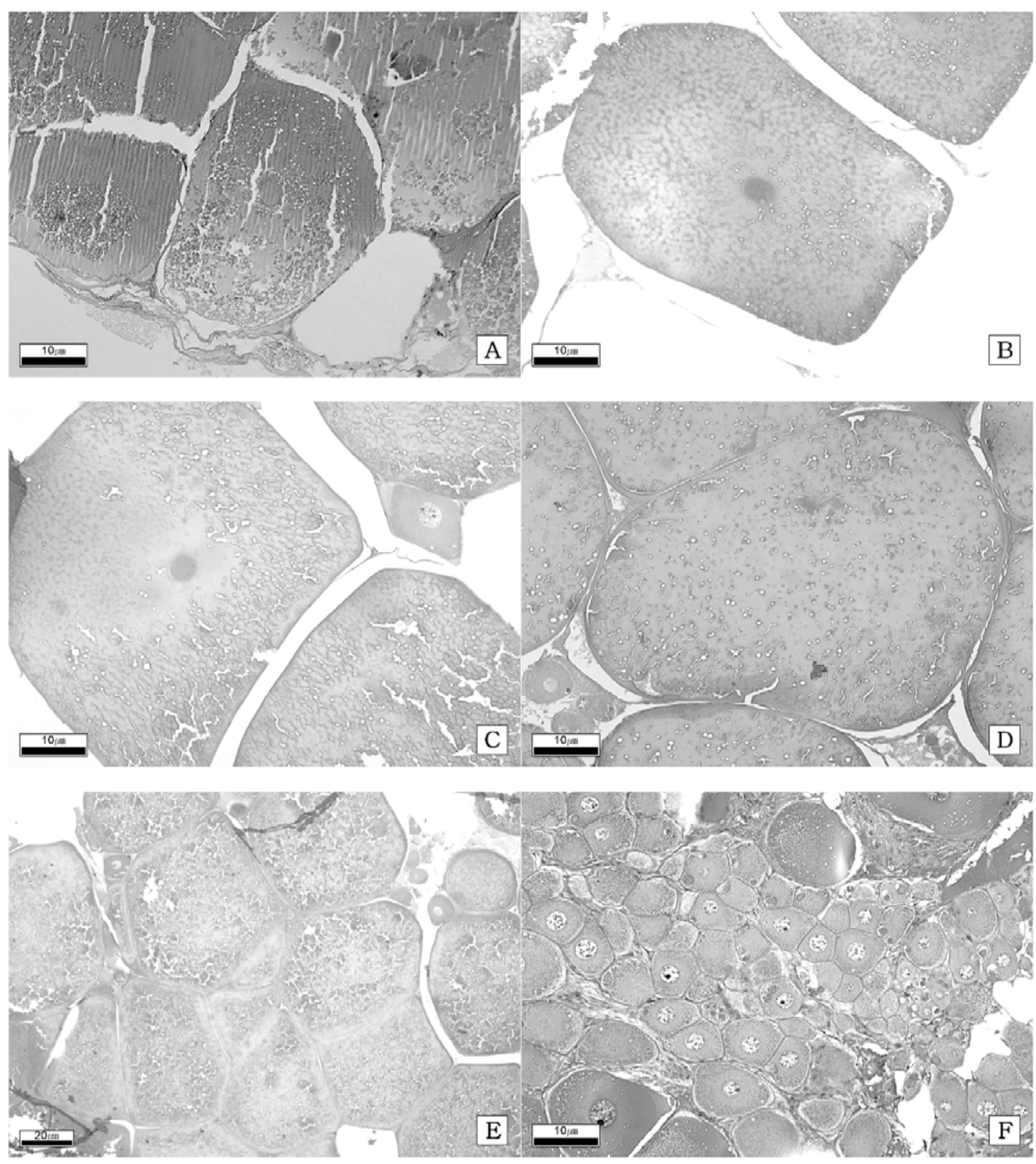

Fig. 6. The development of female ovary Linuparus trigonus. A, B and C, maturing stage from Feb. to June(A, Feb.; B, May; C, June); D and E, matured stage between July(D) and Aug.(E); F, spawn or after spawn stage in Sep.(H\&E, $\times$ 100). 
터 5 월 까지 의 성숙분열기 및 6 월 부터 7 월 말까지 의 성숙기로 7 월 말부터 8월 초순을 완숙기로 파 악한 $\operatorname{Kim}(1977)$ 의 연구 결과보다 빨라졌다. 이 러한 펄닭새우의 성숙시기 변화는 서식해역인 제주연안의 30 년 전보다 $0.27^{\circ} \mathrm{C}$ 상승한 평균수 온의 영향으로 추측된 다(Unpublished data). 또 한, 암컷의 외포란 개체는 8 월 에 1 미, 9 월에 2 미 로 총 3 개체만이 채집되었고, 채집개체의 외포 란의 색 깔은 노랑색이나 주황색 으로 아직 안점 이 형성되지 않았거나, 안점이 형 성된 단계의 것 들로, 부화 직전단계 아니 었다. Bishop and Williams(1986)는 펄 닭새 우가 은신처 생 힐을 한 다는 것을 언급하었는데, 본 연 구에서 나타난 부 화직전 외 포란을 가진 개체가 채집되지 않은 것 은 부화시기가 되면 펄 닭새 우가 은신처 생활을 하거나, 깊은 수심으로이동에 따른 것으로 추측 된 다. 또한, 포란수는 143,360 과 189,504 립으로 각각나타났다.

\section{결 론}

연구기간 동안 제주도 연안에 서 어획된 펄 닭 새우의 성숙크기는 갑각장 $105.0 \mathrm{~mm}$ 로 나타났 으며, 암컷의 생식소 숙도지수는 7 월이 가장높 았으며, 외 포란 개체의 출현은 8,9 월 이었다.

\section{사 사}

본 연구는 국립수산과학원(근해어업 자원조 사, RP-2009-FR-043)의 지 원에 의해 수행되었습 니 다.

\section{참고문헌}

Bishop, G.A. and A.B. Williams, 1986. The fossil lobster Linuparus canadensis, Carlile Shale(Cretaceous), Black Hills. Natl. Geogr. Res., 2, 372 -387.

Choi, J.H., J.N. Kim, C.W. Ma and H.K. Cha, 2005. Growth and reproduction of the kishi velvet shrimp, Metapenaeopsis dalei(Rathbun, 1902)(Decapoda, Penaeidae) in the western sea of Korea. Crustaceana, 78, 947 -963.
Haddy, J.A., D.P. Roy and A.J. Courtney, 2003. The fishery and reproductive biology of barking crayfish, Linuparus tirgonus(Von Siebold, 1824) along Queenslands East Coast. Crustaceana, 76, 1189 1200.

Haddy, J.A., D.P. Roy and A.J. Courtney, 2007. The fishery and reproductive biology of barking crayfish, Linuparus trigonus(Von Siebold, 1824) in the Queensland east coast trawl fishery. In: Report to the Fisheries Research and Development Corporation on Bycatch weight, composition and preliminary estimates of the impact of bycatch reduction devices in Queensland's trawl fishery. Courtney, A.J., J.A. Haddy, M.J. Campbell, D.P. Roy, M.L. Tonks, S.W. Gaddes, K.E. Chilcott, M.F. O’ Neill, I.W. Brown, M. McLennam, E.J. Jebreen, C. van der Geest, C. Rose, S. Kistle, C.T. Turnbull, P.M. Kyne, M.B. Bennett and J. Taylor, eds. Project No. 2000/170, 156 - 165 .

Holthuis, L.B., 1991. FAO species catalogue 13. Marine lobsters of the world. An annotated and illustrated catalogue of the species of interest to fisheries known to date. FAO Fisheries Synopsis. Rome. 125, $111-114$.

Kim, C.H., 1977. Gametogenesis and early development of Linuparus trigonus (Von Siebold). Bull. Korean Fish. Soc., 10, $71-96$.

Lipcius, R.N. and J.S. Cobb, 1994. Introduction; Ecology and fishery biology of spiny lobsters. In: Phillips, B.F., J.S. Cobb, and J. Kittaka, eds. Spiny Lobster Management. Blackwell Scientific, Australia. pp. $1-24$.

Wassenberg, T.J. and B.J. Hill, 1989. Diets of four decapod crustaceans(Linuparus trigonus, Metanephrops andamanicus, M. australiensis and M. boschmai) from the continental shelf around Australia. Mar. Biol., 103, 161 - 167.

2009년 8 월31일 접수

2009년 10 월 27 일 1 차 수정

2009년 10 월 30 일 수리 